\title{
圈 \\ Dividends, Leverage and Endogeneity: A Simultaneous Equations Study on Malaysia
}

\author{
Maziar Ghasemi ${ }^{1}$, Nazrul AB Razak ${ }^{2}$ and Junaina Muhamad ${ }^{3}$
}

\begin{abstract}
Drawing upon preceding empirical studies on the potential endogeneity of both debt and dividends in developed markets, this study investigates two-way causal relationships that can exist between payout decisions and debt policies in Malaysian listed companies. The analysis is performed by applying a simultaneous equations model (SEM) on a sample of 267 listed firms on the Main board of Bursa Malaysia during 2006-2014. The main findings indicate that when dividend is treated as endogenous, there is a positive impact on leverage. However, leverage is found to have a simultaneous negative impact on dividends. The findings also show that liquidity and performance positively affect dividends, although they have a negative effect on leverage. Additionally, this study documents an inverse relation between tangibility and debt, a direct relation between reputation and debt, and also confirms that larger firms tend to pay out a higher percentage of dividends per share.
\end{abstract}

JEL Classification: G35.

Keywords: Agency Theory, Bursa Malaysia, Dividends, Endogeneity, Leverage, Simultaneous Equations Models.

\footnotetext{
${ }^{1}$ Putra Business School, Universiti Putra Malaysia

${ }^{2}$ Universiti Putra Malaysia. Corresponding author.nazrul@upm.edu.my.

${ }^{3}$ Universiti Putra Malaysia
} 


\section{INTRODUCTION:}

Numerous studies in economics and finance have examined the determinants of dividends (Denis \& Osobov, 2008; Miller \& Rock, 1985) and debt policy (Antoniou, Guney, \& Paudyal, 2006; Bolton \& Scharfstein, 1996), separately. However, in the academic literature it is established that debt and dividends are interrelated (Faulkender, Milbourn, \& Thakor, 2006; Kim Ph, Rhim, \& Friesner, 2007). Additionally, based on the agency theory, Jensen et al. (1992) argued that there are both direct and indirect relationships between dividend and leverage policies. This interrelation is obviously due to the fact that the dividend payment determines retention and hence the capital structure (Aggarwal \& Kyaw, 2010). Capital structure policies have the underlying aim of maximizing the value of a firm (Ross, 1977). Jensen and Meckling (1976) also mentioned that based on the agency cost, the optimal capital structure will be determined by minimizing the cost that arises from the conflict between the two parties namely; owners and managers. Moreover, Malaysian firms used the dividend policy to reduce the agency problems (H. J. A. Ahmed, 2008). Additionally, dividend decisions are considered in the corporate governance mechanism which is influenced by other instruments (Esfahani Zahiri \& Jaffar, 2012).

One of the conflicts about the dividend policy in Malaysian public listed companies is related to personal tax exemptions, where managers are reluctant to cut or avoid omitting dividends even when the performance of the companies is deteriorating due to the shareholders' pressure (Ling, Abdull Mutalip, Shahrin, \& Othman, 2008). In Malaysia, there is no standard procedure or policy for governing corporate dividend payments. As such, listed firms are free to decide how much and when during a specific financial business year to pay out dividends as long as they comply with the firms' Act 1965 (Section 365-1)(Chan \& Devi, 2009). Given the lack of a viable bond market, bank loans is the most important debt resource for Malaysian firms (Fraser, Zhang, \& Derashid, 2006). In addition, capital structure is very much dependent on the ownership structure (Ebel Ezeoha \& Okafor, 2010) and Malaysia is concentrated on the ownership structure which include high percentages of family ownership (Claessens \& Djankov, 1999), GLCs ownership (Mokhtar, 2005), and managerial ownership (Mustapha, Ismail, \& Minai, 2011). The purpose of this research is to shed some light on the interrelationship between payout policy and debt decision in the Main market of Bursa Malaysia. To the best of the authors' knowledge, it is the first study that investigates the two-way causal relationship between debt and dividend policy in the Malaysian context. Besides, the main results support the simultaneous mutual relations between debt and dividend policy in the Malaysian market. The rest of the research is categorized as follows: section 2 reviews related literature, section 3 explains data collection procedures and relevant methodology, section 4 discusses the findings and finally, section 5 concludes the findings of this study.

\section{LITERATURE:}

This section reviews the relevant empirical and theoretical literature that depicts the studies of interrelationship between leverage and dividends, and also the financial determinants of leverage and dividends. 


\section{Interrelationship between Dividends and Leverage:}

Agency Theory suggests that the payment of dividends reduces the free cash flow available to the managers and attempts to minimize the agency conflicts (Easterbrook, 1984). Moreover, Easterbrook (1984) revealed that dividends might keep the firm in the capital market because they could monitor managers at a lower cost. The Agency Theory also suggests that debt mitigates shareholder-manager agency problems (H. J. A. Ahmed, 2008) by inducing lenders to monitor reducing the free cash flow available to the managers and force managers to focus on the value maximization when facing the threat of bankruptcy (Grossman \& Hart, 1982; Zwiebel, 1996). Therefore based on the Agency Theory, dividends and leverage can be substituted to solve the agency issue. Recently, scholars explain the agency theory based on the two hypotheses; namely, convergence of interest and entrenchment hypotheses. Entrenched management is a condition that managers have so much power which causes them to extract larger perquisites and higher wages from shareholders and prefer their benefits rather than shareholders' interest (Weisbach, 1988). Since, Malaysian managers are commonly powerful (based on the high level of shareholding and also family connections), therefore debt and dividends could be substitutes or complements in reducing the agency cost ( $\mathrm{M}$ Ghasemi, Ab Razak, \& Hassan, 2015). The policies are substitutes if the convergence of interests hypothesis is effective (Faccio, Lang, \& Young, 2001; Rozeff, 1982) or complements if the entrenchment hypothesis is effective (Persson, 2014). If the entrenchment theory is effective, shareholders could use a combination of debt and dividends to monitor managers because managers cannot be motivated by being offered more ownership stakes. This finding suggests that dividends should be positively related to debts.

Meanwhile, Myers and Majluf (1984) explained that firms follow a hierarchy of financial decisions when establishing their capital structure. In fact, the Pecking Order Theory is based on the presence of asymmetric information between managers and outside investors and the assumption that managers act in the interest of existing shareholders (Shen, 2014). Initially, firms finance projects with the retained earnings first because this finance method incurs no flotation costs and requires no disclosure of the firm's financial information (Bevan \& Danbolt, 2002). If the retained earnings are not sufficient, the firms will go for debt (DeAngelo \& DeAngelo, 2007), and if further financing is required, the last option for the firm is to issue equity. Therefore, a higher level of dividends payout will lead to a higher level of debt to finance new investments.

However, Brook, Charlton Jr, and Hendershott (1998) explicitly stated that there is no reason to believe that corporate dividend policy is driven by a single goal. To answer why dividends is so complicated, Ross, Westerfield, and Jordan (2008) argue that the important elements of dividends are not difficult to identify but the interactions between those elements are complex and no easy answer exists. Additionally, leverage policy is not an independent decision, but rather simultaneously determined with other factors such as firm's dividend policy (Crutchley, Jensen, Jahera Jr, \& Raymond, 1999). Hence, some scholars investigated the concurrent interrelationship between leverage and dividends. For instance, Kim $\mathrm{Ph}$ et al. (2007) and Faulkender et al. (2006) indicated a significant positive impact of leverage on dividends. Furthermore, the findings of Persson (2014) disclosed a positive two-way causal relation between total debts and dividends. Based on the finding by Vo and Nguyen (2014), however, there is a substitution relationship between leverage and dividends in the mechanism of controlling the agency conflicts. 


\section{Debt Determinants:}

Theoretical predictions on the effect of profitability on leverage are contradictory (Morri \& Cristanziani, 2009). Based on POT, firms prefer internal finance resources to external ones, therefore the existence of a negative relationship between leverage and performance is predictable(Ahmad \& Aris, 2015; Sogorb-Mira, 2005). Jensen (1986) predicts a positive relationship between firm's profitability and financial leverage if the market for corporate control is successful because debt decreases the FCF generated by profitability. A recent study by Qureshi, Imdadullah, and Ahsen (2012) also supports this result and determines that profitability is positive and significantly related to debt ratio. However, Affandi, Mahmood, and Shukur (2012) mention that profitability does not have a significant contribution in the capital structure decision in property industry in the Malaysian market.

The tangible assets of a company may be considered as the representative of the real pledges that a company may offer to the creditors. Thus, the significance of such assets among the total assets impresses debt level of a company. It means, increasing the warranties which are offered by the company leads to satisfying its commitments that arise from contracted debts (Baharuddin, Khamis, Mahmood, \& Dollah, 2011; Chung, 1993). On the other hand, tangible assets provide insignificant collateral values in developing countries because of the weak and inefficient regulatory, legal systems, and secondary market. Consequently, an inverse relationship is also predicted and some results obtained from different pieces of research also prove this expectation (Mazur, 2007). Recently Maziar Ghasemi and Ab Razak (2016) studied the effect of different liquidity ratios on different leverage ratios and the results revealed that current ratio had a negative effect on the debt/equity and debt/asset ratios among the listed firms in Bursa Malaysia.

Liquidity has a significant effect on the conservative debt policy when the company has ample liquid assets. Thus, liquidity policies are necessary to ignore potential risks. Therefore, the company will follow the "pecking order style" to finance investments (Deesomsak, Paudyal, \& Pescetto, 2004; Rajan \& Zingales, 1995). However, Morellec (2001) indicates when bond covenants limit the assets' disposition, then asset liquidity increases debt capacity. An argument for a negative relationship is debated by Myers and Rajan (1998) who argue that in the condition of high agency costs of liquidity outside the creditors limit, the amount of debt financing is accessible to the firm. Hence, a negative relationship between liquidity and debt may be expected.

Older firms may establish a good reputation, so they can easily borrow at lower interest rates. That is, the reputation of a firm may affect its leverage capability, since it reduces the conflicts between the company and its lenders (Diamond, 1989). Empirical results suggest a direct relationship between the age of a business and leverage (Lien, Piesse, Strange, \& Filatotchev, 2005). Though, Pecking Order Theory predicts an inverse relationship between leverage and the age of a business as older firms are relatively more stable. In addition, experienced companies have upper internally generated funds and consequently they need less external financing (Myers \& Majluf, 1984).

\section{Dividend Determinants}

In numerous studies, performance has always been considered as a primary indicator of dividend payout ratio (Aivazian, Booth, \& Cleary, 2003; Anil \& Kapoor, 2008; Ben Naceur, Goaied, \& Belanes, 2006). Based on the agency theory, shareholders expect managers of highly profitable firms to pay higher dividends in order to reduce the agency costs (Aivazian et al., 2003; Li, 
Moshirian, Nguyen, \& Tan, 2007). However, the results on the relation of dividend payout and profitability are mixed. Some studies found negative impacts (Amidu \& Abor, 2006; Kania \& Bacon, 2005), although others indicate an insignificant effect of performance on dividends (Kato, Loewenstein, \& Tsay, 2002; C. Mehta, Jain, \& Yadav, 2009).

A large company is further possible to be mature and hence has an easier availability to the capital market and could be able to pay more dividends. That is, the big size companies pay higher dividends and smaller size companies pay fewer dividends (H. Ahmed \& Javid, 2008; Nikolaos, 2005). Also some scholars found the positive effect of the firm size on dividends in Bursa Malaysia (Al-Twaijry, 2007; Ling et al., 2008). However, based on the findings of a study by Breuer, Rieger, and Soypak (2014), payout policies across 29 countries show that there are insignificant effects of the size of firms on Div/Cash, Div/EBIT, and Div/Sales.

A firm's liquidity is an important factor that affects the distribution of cash dividends. Firms with higher cash availability, pay higher dividends than other firms with insufficient cash. This positive relationship is supported by the signaling theory of dividend policy (Ho, 2003). In addition, Appannan and Sim (2011) studied dividend determinants due to the listed companies in KLSE during 2004 to 2008 and showed the positive effect of liquidity on the payout policy. However, some empirical studies indicate that there are no significant relationship between liquidity and profitability in some developing markets such as; Indian Information Technology sector (Anil \& Kapoor, 2008), Abu Dhabi Stock Exchange (A. Mehta, 2012), and listed manufacturing firms in Sri Lanka Niresh (2012).

\section{DATA AND METHODOLOGY:}

\section{Data and Sample:}

The sample data consists of the firms listed on the Main market of Bursa Malaysia and covers a nine-year period from 2006 to 2014. The data sources are OSIRIS and DATASTREAM databases. This study concentrates on industrial products, properties industry, consumer products, trading and services, plantation, construction, and technology sectors of the Main board of Bursa Malaysia. This study investigates all the companies which have paid dividends continuously and used debts in the capital structure. Moreover, companies that ceased to be quoted in the stock market prior to 2014 and those that are listed in the Main market after 2006 are excluded from the sample. Finally, 267 firms were qualified for the inclusion in the sample based on the continuity and accessibility of published financial statements from 2006 to 2014 . The control variables that are used for the analysis include liquidity, reputation, firm size, asset tangibility (warrant), and firm profitability. Table 1 displays the description and measurement of each variable. 
Table 1. Variables and Their Proxies

\begin{tabular}{ll}
\hline VARIABLE & PROXY \\
\hline $\begin{array}{l}\text { Dependent } \\
\text { Dividends } \\
\text { Control } \\
\text { Profitability }\end{array}$ & $\begin{array}{l}\text { Total Debt To Total Equity Ratio } \\
\text { Dividends Per Share Ratio }\end{array}$ \\
Liquidity & ROE= Net Profit/ Total Equity \\
Size & $\frac{\text { Current Assets-Current Liability }}{\text { TotalAsset }}$ \\
Reputation & Natural Logarithm of Total Asset \\
Asset Tangibility & Number of Years Established \\
& $\frac{\text { Tangible Assets }}{\text { Total Assets }}$ \\
\hline
\end{tabular}

\section{Method and Model}

According to Ary, Jacobs, and Razavieh (2002), a research design represents the basic structure of a study and serves as a guide for conducting a research. Shareholders and managers use a combination of dividends and leverage instruments to mitigate their concerns about the agency conflicts. Moreover, there are possibilities of the interrelation between these instruments. Therefore a model should be used that considers the simultaneous interrelations between these instruments. In order to fulfill the purpose of this study which is investigating the simultaneous interrelationship between dividends and leverage, the following model is designed based on two equations in which the dependent variables are dividends and leverage.

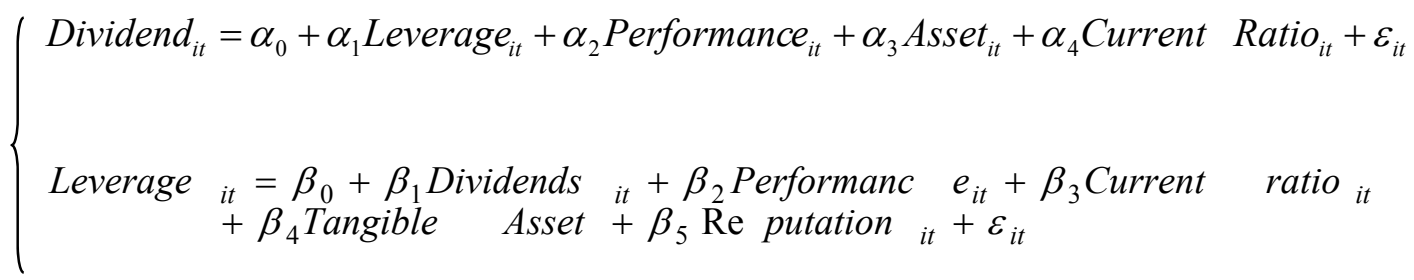

Where: $i$ denotes the firm (cross section dimension) and $t$ denotes time (time series dimension). Dividends and leverage are dependent and endogenous variables and other variables are the control variables, pooling $N$ cross sectional observations and $T$ time series observations. $\alpha_{0}$ and $\beta_{0}$ are constant terms and the intercept across cross sectional observations, and $\varepsilon_{i t}$ is the error term. Statistically, there are two methods to estimate simultaneous equation models (Green, 2003): (1) single-equation methods or limited information methods, such as 2SLS, and (2) system methods or full information methods, such as 3SLS. Hence, to solve the above mentioned model and find out the simultaneous interrelationship between the dependent variables, 2SLS and 3SLS econometrics methods will be used. The 3SLS produces more efficient estimates than 2SLS if each equation does not consist of identical regressores, and also 3SLS is a more appropriate technique for the policy investigation (Davidson \& MacKinnon, 1995). Wooldridge (2012) also proposes that the 2SLS method is more robust and consistent in the situation that the 
interest of the research is just in the special equation of a model. Moreover, Gujarati (2012) suggests that as long as there is a great sample size and also there are no lagged endogenous factors, 2SLS is preferred.

Generally, in order to estimate simultaneous equation systems as different estimators, using both 2SLS and 3SLS methods would be usual approaches (Bhagat \& Bolton, 2008; Persson, 2014).To follow a common method among scholars who studied simultaneous effects between financial factors, dividends and leverage also will be evaluated by OLS for comparing the results of simultaneous equations models and a simple regression will also be used in determining the magnitude of the simultaneous bias. In other words, the comparison between simultaneous equation models (2SLS and 3SLS) with OLS helps readers to have a better understanding of the interrelation effects between dependent variables. For instance, Persson (2014) presents 2SLS, 3SLS, and OLS to assess the simultaneous interrelation among managerial ownership, dividend and leverage. Drakos and Bekiris (2010) reported 2SLS, 3SLS, and OLS to compare simultaneous effects between managerial ownership and performance. Kim $\mathrm{Ph}$ et al. (2007) reported 3SLS and OLS for evaluating interrelationships among managerial ownership, dividend, and leverage.

\section{EMPIRICAL RESULTS:}

\section{Descriptive Statistics:}

Table 2 presents the descriptive statistics of the dependent and independent variables.

The ratio of debt to equity ranges from $0 \%$ to $404 \%$ with the average of $41.10 \%$. These statistics indicate that some of the sample companies are highly leveraged and some of them do not consider debt in the capital structure. The mean value for DPS which is the dependent variable of this study, is .066. It indicates that the average dividend payout of the firms under investigation has been .066 ringgit ( $6.6 \mathrm{Sen}$ ). The mean of the current ratio equals to 3.402 that supports the results of the studies in Malaysia. For instance, the findings of Maziar Ghasemi and Ab Razak (2016)'study showed that during 2010 to 2013, the mean has been 3.31 in the Main market of Bursa Malaysia. The average age that the firms are enlisted in Bursa Malaysia is about 14 years. The mean of the company size equals to 13.08 and when compared with 12 from the study by Suhaila, Mahmood, and Mansor (2008) between years 2000 to 2005, it can be inferred that the listed companies enlarged during these years. In addition, tangible assets of listed companies in the main market made up $32.6 \%$ of their total assets and Profitability is measured by return on equity and has a mean value of 10.076 percent.

Table 2. Descriptive Statistics

\begin{tabular}{lccccc}
\hline Variables & Observation & Mean & Std. Dev. & Minimum & Maximum \\
\hline Debt/Equity & 2403 & .411 & .507 & 0 & 4.04 \\
DPS & 2402 & .066 & .066 & 0 & 1.4 \\
Current Ratio & 2290 & 3.402 & 4.283 & .114 & 40 \\
ROE & 2402 & 10.076 & 9.364 & -40 & 77 \\
Ln( Total Asset) & 2403 & 13.086 & 1.274 & 10 & 18.081 \\
Reputation (Age) & 2403 & 14.067 & 6.222 & 1 & 30
\end{tabular}


Tangibility

2403

.326

.192

0

.940

Table 3 displays the correlations among all the dependent and independent variables. It is observed that all correlation coefficient values in this table are relatively low and their values are less than $34 \%$ in $5 \%$ significant level except for the correlation between reputation and Ln (total asset) which are in different equations. Therefore, there is no cause for being concerned about multicollinearity among the variables.

Table 3 Pearson Correlations Matrix

\begin{tabular}{|c|c|c|c|c|c|c|c|}
\hline & Debt/Equiy & DPS & $\begin{array}{l}\text { Current } \\
\text { Ratio }\end{array}$ & ROE & $\begin{array}{l}\text { Ln } \\
\text { (Total } \\
\text { Asset) } \\
\end{array}$ & $\begin{array}{l}\text { Reputation } \\
\text { (Age) }\end{array}$ & $\begin{array}{l}\text { Tangibili } \\
\text { ty }\end{array}$ \\
\hline Debt/Equity & 1.000 & & & & & & \\
\hline DPS & $-0.145 * *$ & 1.000 & & & & & \\
\hline Current Ratio & $-0.333 * *$ & $0.079 * *$ & 1.000 & & & & \\
\hline ROE & $-0.092 * *$ & $0.366^{* *}$ & -0.033 & 1.000 & & & \\
\hline $\begin{array}{l}\text { Ln( } \quad \text { Total } \\
\text { Asset })\end{array}$ & $0.341 * *$ & $0.248 * *$ & $-0.185^{* *}$ & $0.084 * *$ & 1.000 & & \\
\hline $\begin{array}{l}\text { Reputation } \\
\text { (Age) }\end{array}$ & $0.053 * *$ & $0.281 * *$ & 0.015 & $-0.074 * *$ & $0.584 * *$ & 1.000 & \\
\hline Tangibility & -0.001 & 0.004 & $-0.176 * *$ & $-0.037 *$ & $-0.072 * *$ & $-0.087 * *$ & 1.000 \\
\hline
\end{tabular}

\section{Endogeneity Test:}

Endogeneity is an issue that plagues most empirical pieces of research in corporate governance (Börsch-Supan \& Köke, 2002). Davidson and MacKinnon (1995) suggested the Durbin-WuHausman (DWH) test for checking the endogeneity problem. The result of DWH indicates that the null hypothesis of no endogeneity at the $10 \%$ level is rejected for Leverage $(\mathrm{F}(1,2283)$ $=4440.69$ Prob $>F=0.000)$, the results also show that Dividend is endogenous as well ( $F(1$, $2282)=1809.90$ Prob $>F=0.000$ ). Since the endogeneity problem is initially founded in this study, then, OLS may lead to inconsistent and biased estimates in this study and using simultaneous equations model (SEM) will be a suitable option to deal with the matter.

\section{Model Identification Tests:}

In order to identify a model, two conditions should be met. The first one is 'order condition' and the second one is 'rank condition' (Wooldridge, 2012). The rank condition specifies whether the structural equation which is being checked for identification can be distinguished from a linear combination of all structural equations in the simultaneous equation system. The results show that the model of study has rank conditions (based on checking the rank condition by Stata 13). An equation satisfies the order condition of identification in a SEM, if the number of excluded exogenous variables from the equation is at least as large as the number of endogenous righthand side variables in the equation (Wooldridge, 2012). Since in the equations of the model, the number of excluded exogenous variables is greater than the number of endogenous variables, therefore Sargan-Hansen test is needed to be applied for over identified restrictions. The results 
of the 3SLS model $($ Chi-sq $=0.040 \rho$-value $=0.841)$ and 2 SLS model $($ Chi-sq $=0.044 \rho$-value $=$ 0.834 ) show that the models are identified.

\section{Comparison between 3SLS And 2SLS}

Choosing between 3SLS and 2SLS is an important issue in this study. To resolve this problem, this research conducted the Hausman specification (HS) test (Hausman, 1978), which examines the specification of the system and would be performed on each equation separately. The test chooses one equation in the model and compares 3SLS and 2SLS coefficients. If the null hypothesis cannot be rejected, then the results of 3SLS are efficient and consistent and the result of 2SLS is only consistent. But, if the null hypothesis is rejected, then the results of 3SLS coefficients are inconsistent whereas the result of 2SLS is consistent. As shown in table 4, the evaluation of debt/equity equation based on the 3SLS model is efficient compared to 2SLS model, but their difference is negligible $(\chi 2(\mathrm{df}=5)=0.04 \quad$ Prob $>$ chi $2=1.0000)$, although the result of DPS equation indicates that the 3SLS and 2SLS are the same.

\section{OLS Regressions Tests:}

In the case of autocorrelation, the OLS results are not efficient. Durbin and Watson (1951) Test is applied to check the autocorrelation problem for OLS regressions of leverage and dividends. If, in each of the two OLS regressions, D value is smaller than the value of the lower bound, then correlation exists. The results reveal that both equations have autocorrelation problems. That is, D-Statistics for dividend and leverage are equal to d-statistic $(5,2289)=0.6394524$ and $d$ statistic $(6,2289)=0.4230887$, respectively.

Breusch-Pagan / Cook-Weisberg test is used to find out the potential Heteroskedasticity problem. The results indicate that Dividend regression (chi2 $(1)=3359.85$ Prob $>$ chi2 $=0.000$ ) and leverage regression (chi2 $(1)=127.93$ Prob $>$ chi $2=0.000$ ) have heteroskedasticity problem. Therefore, the Newey-West standard errors will be used in order to obtain heteroskedasticity and auto correlated consistent standard errors (Newey \& West, 1986).

\section{Result and Discussion of Leverage Equation:}

Table 4 shows the findings of the 2SLS, 3SLS, and the OLS estimates for the leverage equation. Considering the 2SLS and the 3SLS findings in Table 4, it can be observed that the coefficient of DPS is negative and significant at the 0.01 level. However, the OLS indicates the reverse result compared to the simultaneous equation models which shows the bias of OLS when DPS has an endogenous variable in a model. This positive effect supports the entrenchment hypothesis of the agency theory, free cash flow hypothesis of the agency theory, and Pecking Order Theory. It means, based on the entrenchment hypothesis, although the dividend payout is increased, managers try to use more debts to mitigate the remaining of the agency issue between themselves and shareholders. On the other words, previous studies argued that dividend payout is rigid and sticky among the listed firms in Bursa Malaysia (Ling et al., 2008) and when considering high percentage of shareholding by managers (Mat Nor \& Sulong, 2007), it can be understood why paying more dividends is not enough to solve the agency conflict and managers have to use other instruments (debt) to reduce the agency matter. In addition, according to the Agency Theory managers try to solve the free cash flow matter by using more dividends; therefore they have lack of internal sources for financing new projects and based on the Pecking Order Theory, they have to use more debts. The finding is consistent with Persson (2014), Kim Ph et al. (2007), but inconsistent with Vo and Nguyen (2014), and Chen and Steiner (1999). 
Table 4 Results for the Leverage Equation

\begin{tabular}{|c|c|c|c|}
\hline D.V.: Debt/Equity & $\begin{array}{l}\text { OLS } \\
\text { (Newey) }\end{array}$ & 2SLS & 3SLS \\
\hline DPS & $\begin{array}{l}-.5084 * * * \\
(.0908)\end{array}$ & $\begin{array}{l}19.0981 * * * \\
(5.2610)\end{array}$ & $\begin{array}{l}19.1582 * * * \\
(5.24559)\end{array}$ \\
\hline Current Ratio & $\begin{array}{l}-.0396 * * * \\
(.0029)\end{array}$ & $\begin{array}{l}-.0958^{* * * *} \\
(.0185)\end{array}$ & $\begin{array}{l}-.0958 * * * \\
(.01849)\end{array}$ \\
\hline Tangible Asset & $\begin{array}{l}-.1198 * * \\
(.0571)\end{array}$ & $\begin{array}{l}-.8921^{* *} \\
(.3179)\end{array}$ & $\begin{array}{l}-.8807 * * \\
(.3124)\end{array}$ \\
\hline ROE & $\begin{array}{l}-.0027 * * \\
(.0013)\end{array}$ & $\begin{array}{l}-.1041^{* * *} \\
(.0276)\end{array}$ & $\begin{array}{l}-.1044 * * * \\
(.0275)\end{array}$ \\
\hline Reputation & $\begin{array}{l}.0080^{* * * *} \\
(.0018)\end{array}$ & $\begin{array}{l}-.1195^{* * *} \\
(.0350)\end{array}$ & $\begin{array}{l}-.1200^{* * *} \\
(.0349)\end{array}$ \\
\hline Cons & $\begin{array}{l}.5325^{* * *} \\
(.0420)\end{array}$ & $\begin{array}{l}2.4734 * * * \\
(.5456)\end{array}$ & $\begin{array}{l}2.4751 * * * \\
(.5448)\end{array}$ \\
\hline Observation Number & 2289 & 2289 & 2289 \\
\hline RMSE & - & 2.1666 & 2.1701 \\
\hline F-value & $49.64 * * *$ & $5.84 * * *$ & - \\
\hline $\begin{array}{l}\chi 2 \\
\text { Hausman Specification } \\
\text { Test between 2SLS and } \\
\text { 3SLS }\end{array}$ & $\begin{array}{l}- \\
-\end{array}$ & $\begin{array}{l}- \\
\chi \quad 2(\mathrm{df}=5) \\
=0.04 \\
\text { Prob }>\text { chi } 2= \\
1.0000\end{array}$ & $29.30 * * *$ \\
\hline
\end{tabular}

NOTE: $* * *, * * *$ Statistically significant at level $0.10,0.05$ and 0.01 . The OLS regression applies Newey-West model standard errors. T statistic is presented within the parentheses. Hausman specification test is performed for choosing between 2SLS and 3SLS based on efficiency and consistency.

The negative coefficient of the current ratio variable is in line with the Pecking Order Theory which explains that the internal resources have priorities compared to the external finance. The results are also consistent with the argument which claims that, in the condition of high agency costs of liquidity, outside creditors limit the amount of debt financing accessible to the firm. This result is consistent with Persson (2014) and Kim Ph et al. (2007), but inconsistent with Ghosh (2007). Unexpectedly, the tangible asset has a negative impact on leverage. However, the result is in contrast with the theoretical literature, but it is mentioned that in the developing markets, such as Poland (Mazur, 2007) and Pakistan (Sheikh \& Wang, 2010). To explain this negative effect, Mazur (2007) argues that in developing countries, because of the weak and inefficient 
regulatory, legal systems and secondary market, the firms cannot use tangible assets in an efficient way; hence, an inverse relationship between tangible asset and leverage is predicted.

The significantly negative relationship between ROE and leverage is also supported by the Pecking Order Theory. The results show that Malaysian listed companies may prefer the internal source for financing new projects compared to loan borrowing. It means a company is able to build up a remarkable amount of retained earnings as it makes profit during years; thus, there would be no cause to seek external financing via debt (Abu Mouamer, 2011).

Moreover, the result is consistent with previous studies in the Malaysian context (Ahmad \& Aris, 2015; Suhaila et al., 2008). Table 4 also shows that the age of the firm has a significant impact on leverage, implying that experienced firms may be more stable and have upper internally generated funds in which they do not require external resources. Moreover, directors of an old company are concerned with the company's reputation and tend to avoid riskier projects and act more prudently. This manner leads to reducing the debt financing in aged firms. This result supports former findings by Ahmad and Aris (2015) in the Malaysian market.

\section{Results and Discussion of Dividend Equation:}

Table 5 shows the results of OLS (Newey-West), 2SLS, 3SLS associated with the dividend equation of the model. The findings show that $\rho$-values and coefficients of variables in 2SLS and 3SLS are the same. As shown in the OLS column, the coefficient of Debt/Equity is -.0468 whereas the 3SLS shows a coefficient equal to -.346, indicating that SEM models present a coefficient with 8 times more values compared to OLS regressions. More debts financing by the firms lead to decreasing the amounts that could be paid to the shareholders. This negative effect of leverage on dividends can be explained based on the effect of the installments. It means shareholders are concerned about free cash flow (FCF); thus managers have to specify the FCF to cover the Loan repayment obligations, and then the shareholders' concern disappears. On the other hand, benefits of debt holders might not be retained when huge amounts of dividends are paid out. Thus, limitations in dividend payments can be found in debt covenants to alleviate this problem. This finding also is in line with the convergence of interest hypothesis in which using more debt leads to decreasing in dividend payout.

Moreover, the result is in contrast with the previous studies in Malaysia (Appannan \& Sim, 2011; Ling et al., 2008), but it is in line with the findings of simultaneous equations studies by Vo and Nguyen (2014) and Chen and Steiner (1999). In addition, the results indicate that the current ratio has a negative effect on dividends that indicates a conservative decision making by the Malaysian managers.

Additionally, increasing performance causes more payments on dividends to the shareholders and this increase is consistent with the Agency Theory, indicating that shareholders expect managers in highly profitable firms to pay out higher dividends in order to reduce the agency costs. Indeed, the Agency Theory suggests that the payment of dividends reduces the FCF available to the managers and attempts to minimize agency conflicts (Jensen, 1986). Shareholders, therefore, expect managers of highly profitable firms to pay higher dividends in order to reduce the agency costs ( $\mathrm{Li}$ et al., 2007). This finding confirms previous studies in Malaysia (Appannan \& Sim, 2011; Ling et al., 2008). 
Expectedly, the size of the firm shows a significant positive effect on dividends, indicating that a large company is more possible to be mature and also has an easier availability to the capital market and could be able to pay more dividends. This finding is in line with the study by AlTwaijry (2007) in Malaysia.

Table 5 Results for the Dividend Equation

\begin{tabular}{|c|c|c|c|}
\hline D.V.: DPS & $\begin{array}{l}\text { OLS } \\
\text { (Newey) }\end{array}$ & 2SLS & 3SLS \\
\hline Debt/Equity & $\begin{array}{l}-.0468 * * * \\
(.0049)\end{array}$ & $\begin{array}{l}-.3460 * * * \\
(.0459)\end{array}$ & $\begin{array}{l}-.3460 * * * \\
(.0459)\end{array}$ \\
\hline Ln (Asset) & $\begin{array}{l}.0301 * * * \\
(.0024)\end{array}$ & $\begin{array}{l}-.0661 * * * \\
(.0062)\end{array}$ & $\begin{array}{l}.0661 * * * \\
(.0062)\end{array}$ \\
\hline ROE & $\begin{array}{l}.0042 * * * \\
(.0006)\end{array}$ & $\begin{array}{l}.0021 * * * \\
(.0005)\end{array}$ & $\begin{array}{l}.0021 * * * \\
(.0005)\end{array}$ \\
\hline Current Ratio & $\begin{array}{l}.0024 * * * \\
(.0005)\end{array}$ & $\begin{array}{l}-.0075^{* * *} \\
(.0017)\end{array}$ & $\begin{array}{l}-.0075^{* * *} \\
(.0017)\end{array}$ \\
\hline Cons & $\begin{array}{l}-.3586^{* * *} \\
(.0311)\end{array}$ & $\begin{array}{l}-.6501 * * * \\
(.5490)\end{array}$ & $\begin{array}{l}-.6501^{* * * *} \\
(.0589)\end{array}$ \\
\hline Observation Number & 2289 & 2289 & 2289 \\
\hline RMSE & - & .1731 & .1730 \\
\hline F-value & $53.20 * * *$ & $74.57 * * *$ & - \\
\hline $\begin{array}{l}\chi 2 \\
\text { Hausman Specification } \\
\text { Test between 2SLS and } \\
\text { 3SLS }\end{array}$ & $\begin{array}{l}- \\
-\end{array}$ & $\begin{array}{l}- \\
\chi \quad 2(\mathrm{df}=5) \\
=0.00 \\
\text { Prob }>\text { chi } 2= \\
1.0000\end{array}$ & $\begin{array}{l}298.92 * * * \\
-\end{array}$ \\
\hline
\end{tabular}

NOTE: $* * *, * *, *$ Statistically significant at level $0.10,0.05$ and 0.01. The OLS regression applies Newey-West model standard errors. T statistic is presented within the parentheses. Hausman specification test is performed for choosing between 2SLS and 3SLS based on efficiency and consistency.

\section{CONCLUSIONS:}

This paper examines the simultaneous determination of debt and dividends in Bursa Malaysia. Like previous studies, this paper applies a simultaneous equation framework, which allows for the possibility of determining the endogeneity of dividends and leverage.

This study also considers the entrenchment and the convergence of interests (COI) hypotheses and their abilities to explain the dividends and leverage roles to decrease agency conflicts. 
Moreover, this study confirms the notion that the entrenchment hypothesis and the COI hypothesis cannot assume mutually exclusive.

The main results are as follows: (i) There are two-way relationships between leverage and dividends, in which, leverage has a negative impact on dividends whereas dividend positively affects leverage. (ii) These results show that listed firms use dividends and leverage to solve the agency conflicts related to the free cash flow, although leverage and dividends are not mutually exclusive in the Malaysian market. (iii) The results imply that shareholders and managers put more emphasis on leverage to mitigate the free cash flow problem. (iv) Malaysian firms follow the Pecking Order Theory in order to finance new projects.

Unlike most existing research, which utilizes ordinary least squares method and finds inconclusive and sometimes contradictory results about the nature of these relationships, this study shows that applying simultaneous equation models is justified and essential, since both two variables reveal to be simultaneously determined.

The findings indicate that the results of 3SLS and 2SLS analyses are similar. However, based on the OLS analysis, the results of the estimations between dividends and leverage are strongly different from 3SLS and 2SLS. It means, in the leverage equation, both the sign and magnitude for the coefficient of leverage are different from the results of 3SLS and 2SLS. In addition, in the dividend equation, a large difference was found between the magnitude of the coefficients of OLS and 3SLS. Therefore, 3SLS and 2SLS are empirically justified over the OLS due to the large differences in the sign and magnitudes of the endogeneity. However, this study utilizes the data on the listed companies in Bursa Malaysia; therefore, the findings may be limited to this population. Future studies in this area may focus more on the two approaches; first, using other econometric methods may be used as another way for proving these findings. Second, this study used the total debt for calculating leverage. Hence, this study can be extended by investigating the interrelationships between the short-term and long-term debts with dividends.

\section{REFERENCES:}

Abu Mouamer, F. M. (2011). The determinants of capital structure of Palestine-listed companies. The Journal of Risk Finance, 12(3), 226-241. https://doi.org/10.1108/15265941111136969

Affandi, S., Mahmood, W. M. W., \& Shukur, N. A. (2012). Capital Structure of Property Companies in Malaysia Based on Three Capital Theories. South East Asian Journal of Contemporary Business, Economics and Law, 1(1), 131-136.

Aggarwal, R., \& Kyaw, N. A. (2010). Capital structure, dividend policy, and multinationality: Theory versus empirical evidence. International Review of Financial Analysis, 19(2), 140-150. https://doi.org/10.1016/j.irfa.2010.01.001

Ahmad, N., \& Aris, Y. B. W. (2015). Does Age of the Firm Determine Capital Structure Decision? Evidence from Malaysian Trading and Service Sector. International Business Management, 9(3), 200-207. http://dx.doi:10.3923/ibm.2015.200.207

Ahmed, H., \& Javid, A. Y. (2008). Dynamics and determinants of dividend policy in Pakistan (evidence from Karachi stock exchange non-financial listed firms). Munich Personal RePEc Archive, 25(2), 148-171. https://mpra.ub.uni-muenchen.de/id/eprint/37342

Ahmed, H. J. A. (2008). Managerial ownership concentration and agency conflict using logistic regression approach: Evidence from Bursa Malaysia. Journal of management research, 1(1), 1-10. https://doi.org/10.5296/jmr.v1i1.36 
Aivazian, V., Booth, L., \& Cleary, S. (2003). Do emerging market firms follow different dividend policies from US firms? Journal of financial Research, 26(3), 371-387. https://doi.org/10.1111/1475-6803.00064

Al-Twaijry, A. A. (2007). Dividend policy and payout ratio: evidence from the Kuala Lumpur stock exchange. The Journal of Risk Finance, 8(4), 349-363. https://doi.org/10.1108/15265940710777306

Amidu, M., \& Abor, J. (2006). Determinants of dividend payout ratios in Ghana. Journal of Risk Finance, The, 7(2), 136-145. https://doi.org/10.1108/15265940610648580

Anil, K., \& Kapoor, S. (2008). Determinants of dividend payout ratios-a study of Indian information technology sector. International Research Journal of Finance and Economics, 15(1), 63-71. https://doi.org/10.1111/j.1354-7798.2006.00315.x

Antoniou, A., Guney, Y., \& Paudyal, K. (2006). The determinants of debt maturity structure: evidence from France, Germany and the UK. European Financial Management, 12(2), 161-194. https://doi.org/10.1111/i.1354-7798.2006.00315.x

Appannan, S., \& Sim, L. W. (2011). A Study on Leading Determinants of Dividend Policy in Malaysia Listed Companies for Food Industry Under Consumer Product Sector. Paper presented at the 2 nd International Conference on Business and Economic Research.

Ary, D., Jacobs, L., \& Razavieh, A. (2002). Introduction to research in education . Wadsworth Group: CA.

Baharuddin, N. S., Khamis, Z., Mahmood, W. M. W., \& Dollah, H. (2011). Determinants of capital structure for listed construction companies in Malaysia. Journal of Applied Finance and Banking, 1(2), 115-132.

Ben Naceur, S., Goaied, M., \& Belanes, A. (2006). On the determinants and dynamics of dividend policy. International Review of Finance, 6(1-2), 1-23. http://dx.doi.org/10.2139/ssrn.889330

Bevan, A. A., \& Danbolt, J. (2002). Capital structure and its determinants in the UK-a decompositional analysis. Applied Financial Economics, 12(3), 159-170. https://doi.org/10.1080/09603100110090073

Bhagat, S., \& Bolton, B. (2008). Corporate governance and firm performance. Journal of Corporate Finance, 14(3), 257-273. https://doi.org/10.1016/i.jcorpfin.2008.03.006

Bolton, P., \& Scharfstein, D. S. (1996). Optimal debt structure and the number of creditors. Journal of political economy, 104, 1-25. https://doi.org/10.1086/262015

Börsch-Supan, A., \& Köke, J. (2002). An applied econometricians' view of empirical corporate governance studies. German Economic Review, 3(3), 295-326. https://doi.org/10.1111/1468-0475.00061

Breuer, W., Rieger, M. O., \& Soypak, K. C. (2014). The behavioral foundations of corporate dividend policy a cross-country analysis. Journal of Banking \& Finance, 42, 247-265. https://doi.org/10.2139/ssrn.1804265

Brook, Y., Charlton Jr, W. T., \& Hendershott, R. J. (1998). Do firms use dividends to signal large future cash flow increases? Financial Management, 27, 46-57. https://doi.org/10.2307/3666274

Chan, W., \& Devi, S. (2009). Malaysia's Dividend Rule: A Blot in Corporate Governance? Accountants Today, 29, 26-29.

Chen, C. R., \& Steiner, T. L. (1999). Managerial ownership and agency conflicts: A nonlinear simultaneous equation analysis of managerial ownership, risk taking, debt policy, and dividend policy. Financial Review, 34(1), 119-136. https://doi.org/10.1111/i.15406288.1999.tb00448.x 
Ghasemi, Razak \& Muhamud | Dividends, Leverage and Endogeneity Study in Bursa Malaysia

Chung, K. H. (1993). Asset characteristics and corporate debt policy: an empirical test. Journal of Business Finance \& Accounting, 20(1), 83-98. https://doi.org/10.1111/.14685957.1993.tb00251.x

Claessens, S., \& Djankov, S. (1999). Ownership concentration and corporate performance in the Czech Republic. Journal of Comparative Economics, 27(3), 498-513. https://doi.org/10.1006/jcec.1999.1598

Crutchley, C. E., Jensen, M. R., Jahera Jr, J. S., \& Raymond, J. E. (1999). Agency problems and the simultaneity of financial decision making: The role of institutional ownership. International Review of Financial Analysis, 8(2), 177-197. https://doi.org/10.1016/S10575219(99)00011-3

Davidson, R., \& MacKinnon, J. G. (1995). Estimation and inference in econometrics. Econometric Theory, 11, 631-635. https://doi.org/10.1002/jae.3950100309

DeAngelo, H., \& DeAngelo, L. (2007). Capital structure, payout policy, and financial flexibility. Marshall School of Business Working Paper 916093, 2-6. https://doi.org/10.2139/ssrn.916093

Deesomsak, R., Paudyal, K., \& Pescetto, G. (2004). The determinants of capital structure: evidence from the Asia Pacific region. Journal of multinational financial management, 14(4), 387-405. https://doi.org/10.1016/j.mulfin.2004.03.001

Denis, D. J., \& Osobov, I. (2008). Why do firms pay dividends? International evidence on the determinants of dividend policy. Journal of financial Economics, 89(1), 62-82. https://doi.org/10.2139/ssrn.887643

Diamond, D. W. (1989). Reputation acquisition in debt markets. The journal of political economy, 97(4), 828-862. https://doi.org/10.1086/261630

Drakos, A., \& Bekiris, F. (2010). Corporate performance, managerial ownership and endogeneity: A simultaneous equations analysis for the Athens stock exchange. Research in International Business and Finance, 24(1), 24-38. https://doi.org/10.1016/j.ribaf.2009.01.002

Durbin, J., \& Watson, G. S. (1951). Testing for serial correlation in least squares regression. II. Biometrika, 159-177. https://doi.org/10.1093/biomet/38.1-2.159

Easterbrook, F. H. (1984). Two agency-cost explanations of dividends. The American economic review, 74, 650-659.

Ebel Ezeoha, A., \& Okafor, F. O. (2010). Local corporate ownership and capital structure decisions in Nigeria: a developing country perspective. Corporate Governance: The international journal of business in society, 10(3), 249-260. https://doi.org/10.1108/14720701011051893

Esfahani Zahiri, A., \& Jaffar, R. (2012). The Effect of Corporate Governance and Capital Structure on Dividend Payment: Evidence from Malaysia. Recent Advances in Management, Marketing and Finance, 75-80.

Faccio, M., Lang, L. H., \& Young, L. (2001). Dividends and expropriation. American Economic Review, 54-78. https://doi.org/10.1257/aer.91.1.54

Faulkender, M., Milbourn, T., \& Thakor, A. (2006). Capital structure and dividend policy: two sides of the same coin. Washington University in St. Louis, working paper.

Fraser, D. R., Zhang, H., \& Derashid, C. (2006). Capital structure and political patronage: The case of Malaysia. Journal of Banking \& Finance, 30(4), 1291-1308. https://doi.org/10.1016/i.jbankfin.2005.05.008

Ghasemi, M., \& Ab Razak, N. H. (2016). The Impact of Liquidity on the Capital Structure: Evidence from Malaysia. International journal of economics and finance, 8(10), 130-139. https://doi.org/10.5539/ijef.v8n10p130 
Ghasemi, M., Ab Razak, N. H., \& Hassan, T. (2015). Agency Problem, Managerial Incentive and Financial Controlling Instrument: A Brief Review for Agenda Study in Malaysia. Social Science \& Humanities, 23(s), 39-58.

Ghosh, S. (2007). Leverage, managerial monitoring and firm valuation: A simultaneous equation approach. Research in Economics, 61(2), 84-98. https://doi.org/10.1016/j.rie.2007.03.001

Green, W. (2003). H. Econometric analysis: New Jersey: Prentice Hall.

Grossman, S. J., \& Hart, O. D. (1982). Corporate financial structure and managerial incentives The economics of information and uncertainty (pp. 107-140): University of Chicago Press.

Gujarati, D. N. (2012). Basic econometrics: Tata McGraw-Hill Education.

Hausman, J. A. (1978). Specification tests in econometrics. Econometrica: Journal of the Econometric Society, 1251-1271. https://doi.org/10.2307/1913827

Ho, H. (2003). Dividend policies in Australia and Japan. International Advances in Economic Research, 9(2), 91-100. https://doi.org/10.1007/BF02295710

Jensen, M. C. (1986). Agency cost of free cash flow, corporate finance, and takeovers. American Economic Review, 76(2), 323-329. https://doi.org/10.2139/ssrn.99580

Jensen, M. C., \& Meckling, W. H. (1976). Theory of the firm: managerial behavior, agency costs, and ownership structure. Journal of financial Economics, 3(4), 78-79,305. https://doi.org/10.1016/0304-405X(76)90026-X

Kania, S. L., \& Bacon, F. W. (2005). What factors motivate the corporate dividend decision. ASBBS E-Journal, 1(1), 97-107.

Kato, H. K., Loewenstein, U., \& Tsay, W. (2002). Dividend policy, cash flow, and investment in Japan. Pacific-Basin Finance Journal, 10(4), 443-473. https://doi.org/10.1016/S0927538X(02)00068-9

Kim Ph, Y. H., Rhim, J. C., \& Friesner, D. L. (2007). Interrelationships among capital structure, dividends, and ownership: evidence from South Korea. Multinational Business Review, 15(3), 25-42. https://doi.org/10.1108/1525383X200700011

Li, D., Moshirian, F., Nguyen, P., \& Tan, L.-W. (2007). Managerial ownership and firm performance: Evidence from China's privatizations. Research in International Business and Finance, 21(3), 396-413. https://doi.org/10.1016/j.ribaf.2007.02.001

Lien, Y.-C., Piesse, J., Strange, R., \& Filatotchev, I. (2005). The role of corporate governance in FDI decisions: Evidence from Taiwan. International Business Review, 14(6), 739-763. https://doi.org/10.1016/j.ibusrev.2005.08.002

Ling, F. S., Abdull Mutalip, M., Shahrin, A. R., \& Othman, M. S. (2008). Dividend policy: Evidence from public listed companies in Malaysia. International Review of Business Research Papers, 4(4), 209-222.

Mat Nor, F., \& Sulong, Z. (2007). The interaction effect of ownership structure and board governance on dividends: Evidence from Malaysian listed firms. Capital market review, 15(1 and2), 73-101.

Mazur, K. (2007). The determinants of capital structure choice: evidence from Polish companies. International Advances in Economic Research, 13(4), $495-514$. https://doi.org/10.1007/s11294-007-9114-y

Mehta, A. (2012). An empirical analysis of determinants of dividend policy-evidence from the UAE companies. Global Review of Accounting and Finance, 3(1), 18-31.

Mehta, C., Jain, P., \& Yadav, S. S. (2009). Rationale of Stock Dividends/Bonus Shares: An Empirical Study of Private Sector Enterprises in India. Journal of Financial Management and Analysis, 22(1), 28-39. 
Miller, M. H., \& Rock, K. (1985). Dividend policy under asymmetric information. The journal of finance, 40(4), 1031-1051. https://doi.org/10.1111/j.1540-6261.1985.tb02362.x

Mokhtar, A. (2005). The Malay Way of Business Change. Economist, 376(8440), 1-50.

Morellec, E. (2001). Asset liquidity, capital structure, and secured debt. Journal of financial Economics, 61(2), 173-206. https://doi.org/10.1016/S0304-405X(01)00059-9

Morri, G., \& Cristanziani, F. (2009). What determines the capital structure of real estate companies? An analysis of the EPRA/NAREIT Europe Index. Journal of Property Investment \& Finance, 27(4), 318-372. https://doi.org/10.1108/14635780910972288

Mustapha, M., Ismail, H., \& Minai, B. (2011). Determinants of debt structure: empirical evidence from Malaysia. Paper presented at the Proceedings of the 2nd International Conference on Business and Economic Research.

Myers, S. C., \& Majluf, N. S. (1984). Corporate financing and investment decisions when firms have information that investors do not have. Journal of financial Economics, 13(2), 187221. https://doi.org/10.1016/0304-405X(84)90023-0

Myers, S. C., \& Rajan, R. G. (1998). The paradox of liquidity. Quarterly Journal of Economics, 113, 733-771. https://doi.org/10.1162/003355398555739

Newey, W. K., \& West, K. D. (1986). A simple, positive semi-definite, heteroskedasticity and autocorrelationconsistent covariance matrix (pp. 1-11): National Bureau of Economic Research Cambridge, Mass., USA. https://doi.org/10.3386/t0055

Nikolaos, E. (2005). The Effect of Distribution Earnings and Size of the Firm to its Dividend Policy. International \& Economics Journal, 4(1), 67-74.

Niresh, J. A. (2012). Trade-Off between Liquidity \& Profitability: A Study of Selected Manufacturing Firms in Srilanka. International Refereed Research Journal, 3(4), 34-40.

Persson, R. (2014). Simultaneous determination of Debt, Dividend, and Inside Ownership policies: Evidence from Sweden. Mittuniversitete, 1-12.

Qureshi, M. A., Imdadullah, M., \& Ahsen, T. (2012). What determines leverage in Pakistan? A panel data analysis. African Journal of Business Management, 6(3), 978-985. https://doi.org/10.5897/AJBM11.1535

Rajan, R. G., \& Zingales, L. (1995). What do we know about capital structure? Some evidence from international data. The journal of finance, 50(5), 1421-1460. https://doi.org/10.1111/i.1540-6261.1995.tb05184.x

Ross, S. A. (1977). The determination of financial structure: the incentive-signalling approach. The Bell Journal of Economics, 23-40. https://doi.org/10.2307/3003485

Ross, S. A., Westerfield, R., \& Jordan, B. D. (2008). Fundamentals of corporate finance: Tata McGraw-Hill Education.

Rozeff, M. S. (1982). Growth, beta and agency costs as determinants of dividend payout ratios. Journal of financial Research, 5(3), 249-259. https://doi.org/10.1111/j.14756803.1982.tb00299.x

Sheikh, N., \& Wang, Z. (2010). Financing Behavior of Textile Firms in Pakistan. International Journal of Innovation, Management and Technology, 1(2), 1-6. DOI: 10.7763/IJIMT.2010.V1.24

Shen, C. H.-h. (2014). Pecking order, access to public debt market, and information asymmetry. International Review of Economics \& Finance, 29, 291-306. https://doi.org/10.1016/i.iref.2013.06.002

Sogorb-Mira, F. (2005). How SME uniqueness affects capital structure: Evidence from a 19941998 Spanish data panel. Small business economics, 25(5), 447-457. https://doi.org/10.1007/s11187-004-6486-8 
Suhaila, M. K., Mahmood, W., \& Mansor, W. (2008). Capital structure and firm characteristics: Some evidence from Malaysian companies. University Library of Munich, MPRA Paper Series No.14616.

Vo, D. H., \& Nguyen, V. T.-Y. (2014). Managerial Ownership, Leverage and Dividend Policies: Empirical Evidence from Vietnam's Listed Firms. International journal of economics and finance, 6(5), 274-284. https://doi.org/10.5539/ijef.v6n5p274

Weisbach, M. S. (1988). Outside directors and CEO turnover. Journal of financial Economics, 20, 431-460. https://doi.org/10.1016/0304-405X(88)90053-0

Wooldridge, J. (2012). Introductory econometrics: A modern approach: Cengage Learning. Zwiebel, J. (1996). Dynamic capital structure under managerial entrenchment. The American economic review, 1197-1215. 